\title{
Evaluation of Exhaust Gas Condensing Economizer Installation at Riga CHP Plants
}

\author{
Aris Zigurs ${ }^{1}$, Maris Kunickis ${ }^{2}$, Maris Balodis ${ }^{3}$, Olegs Linkevics ${ }^{4}$, Ilmars Stuklis ${ }^{5}$, Polina Ivanova ${ }^{6}$, \\ ${ }^{1-6}$ JSC Latvenergo
}

\begin{abstract}
In this study, passive exhaust gas condensing economizer installation is evaluated at Riga CHP plants No. 1 and No. 2 to increase efficiency of heat only boilers (HOBs). Five options are investigated: two options for Riga CHP plant No. 1 and three options for Riga CHP plant No. 2. The study provides the analysis of HOBs operation statistics, determination of HOBs operation trends, development of production programmes, as well as economic and sensitivity analysis of the considered options. Based on economic analysis, the best option for installation of passive exhaust gas condensing economizer for Riga CHP-1 and Riga CHP-2 was chosen.
\end{abstract}

Keywords - CHP plant, condensing economizer, dew point, exhaust gas, HOB, latent heat.

\section{Utilization of EXHaust Gas LATENT HeAT}

The exhaust gas condensing economizer is used to recover exhaust gas latent heat. Latent heat is heat amount, which can be absorbed, when the process of phase changes occurs (melting or evaporation). The recovered heat can be used to heat return water from the district heating system. In this way it is possible to increase the HOB efficiency. So the fossil fuel (in our case natural gas) consumption and $\mathrm{CO}_{2}$ emissions can be reduced [1].

The moisture content in exhaust gas is the main factor of heat energy recovery from flue gas, because it determines the exhaust gas dew point. The dew point depends on fuel type, moisture content of excess air and fuel-air ratio. The greater is moisture content, the higher is the dew point of the exhaust gas. In this way it is technologically easier to realize the condensation of flue gas and recovery of latent heat [1].

Exhaust gas has higher moisture content, when such fuels as wood chips and natural gas are combusted. The dew point of flue gases is $50-57^{\circ} \mathrm{C}$, when natural gas is burned. The lowest dew point is in case of liquid fuel [2].

The condensing economizers are divided into two groups:

1) Active condensing economizers;

2) Passive condensing economizers [3], [4].

Active condensing economizer is heat exchange equipment, where exhaust gas additionally is moistened before its condensation. Active economizers are mostly used to increase efficiency of steam boilers and solid fuel HOBs, because of the high exhaust gas temperature. The main disadvantage of these condensing economizers is a short economizer life span because of aggressive (acid or corrosion active) medium, when $\mathrm{NO}$ and $\mathrm{CO}_{2}$ connect with water [3], [4].

Passive condensing economizer is heat exchange equipment with large heat surface, where exhaust gas condenses without additional moistening. Installation feasibility of passive condensing economizers is dependent on the economizer working hours at maximum load. The passive condensing economizer can be used at low return water temperature, because of low dew point of exhaust gas $\left(45-60{ }^{\circ} \mathrm{C}\right)$. It means that HOBs should be operated in base mode. That is why it can be complicated to use passive condensing economizers at cogeneration power plants, because HOBs in CHP plants are mainly operated in peak mode [3], [4].

\section{RIGA CHP PLANTS OVERVIEW}

In this study, the evaluation of passive condensing economizer installation is done at Riga CHP plants. Riga CHP plants No. 1 and No. 2 are one of the most up-to-date power plants in Europe. CHP plant No. 1 consists of gas-steam double block and three natural gas fired HOBs. The thermal capacity of cogeneration unit is $145 \mathrm{MW}$ and the electrical capacity is $144 \mathrm{MW}$. The total thermal capacity of HOBs KVGM-100 is $348 \mathrm{MW}(3 \times 116 \mathrm{MW})$. HOBs No. 1 and No. 2 are connected to one common smoke stack and HOB No. 3 has its own smoke stack [5].

CHP plant No. 2 consists of two cogeneration units No. 1 and No. 2 and a water heating boiler house. The thermal capacity of cogeneration unit No. 1 is $274 \mathrm{MW}$ and electrical power $-413 \mathrm{MW}$ ( $442 \mathrm{MW}$ in condensing mode). The thermal capacity of cogeneration unit No. 2 is $270 \mathrm{MW}$ and electricity power - 419 MW (439 MW in condensing mode) [5].

The water heating boiler house has five natural gas fired HOBs $(5 \times 116 \mathrm{MW})$. So the total thermal capacity of the water heating boiler house is $580 \mathrm{MW}$. From 2009 to 2011, HOBs No. 1, 2, 3, 4 were reconstructed: frontal screen was changed, low $\mathrm{NO}_{\mathrm{x}}$ burners were installed, ventilator and smoke exhauster frequency was increased. HOBs No. 1, 2, 3 are connected to one common smoke stack and HOBs No. 4 \& 5 are connected to the other smoke stack [5].

Natural gas is used as a primary fuel and diesel is used as emergency fuel at Riga CHP plants [5].

\section{A. Analysis of Riga CHP Plants Operation}

The thermal energy production from 2000 to 2014 at Riga CHP plant is represented in Fig. 1. At Riga CHP plant No. 1 thermal energy production by HOBs increased from $31 \mathrm{GWh}$ to $464 \mathrm{GWh}$. So the share of produced thermal energy by HOBs increased from $4.2 \%$ to $49.2 \%$.

At Riga CHP plant Nr. 2 thermal energy production by HOBs increased from $121 \mathrm{GWh}$ to $640 \mathrm{GWh}$. So the share of 
thermal energy produced by HOBs increased from $6.6 \%$ to $49.6 \%$.

GWh

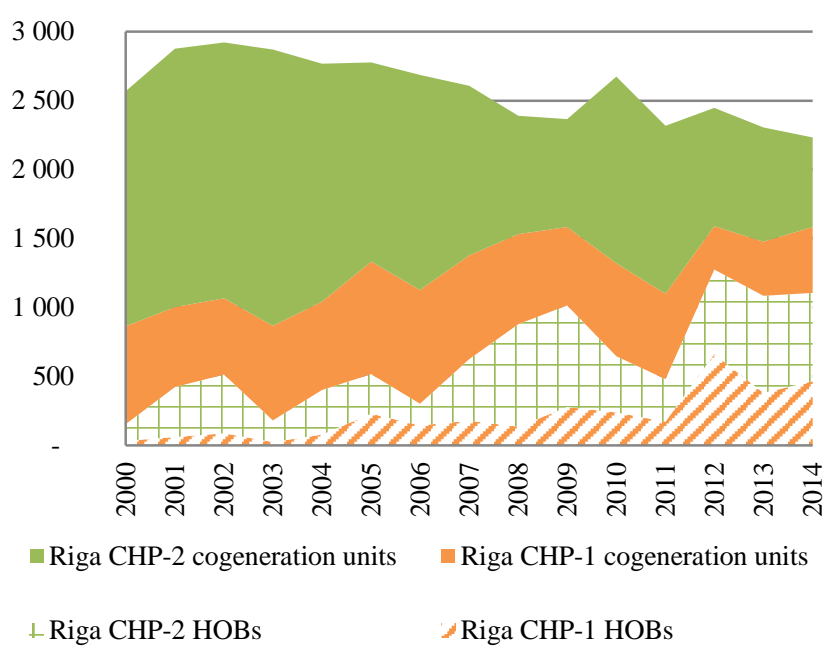

Fig. 1. Thermal energy production at Riga CHP plants from 2000 to 2014.

Fig. 2 reflects thermal energy production at Riga CHP plants in 2014. The HOBs share of total thermal energy demand was $15 \%-30 \%$ during the summer. In winter, thermal energy production of HOBs increased and its share reached $50 \%-70 \%$ of total energy productions. During the flood period (in spring) the HOBs provided $70 \%-100 \%$ of total energy production.

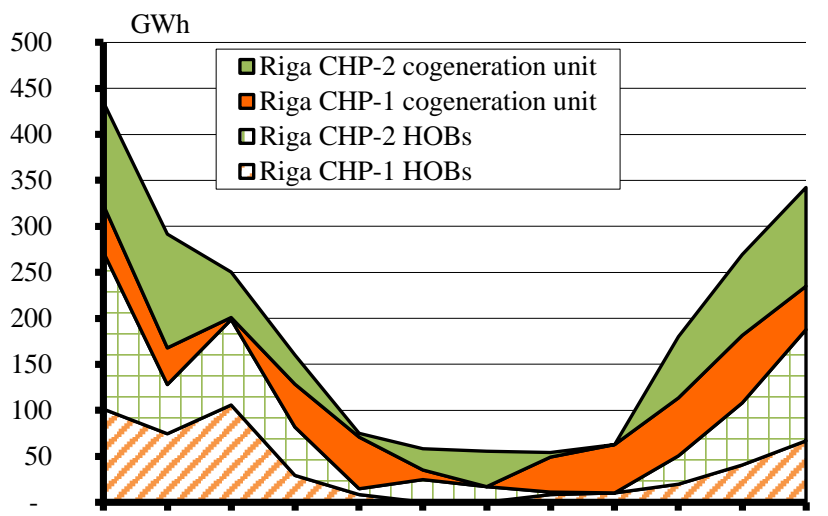

Jan. Feb. Mar. Apr. May June July Aug. Sep. Okt. Nov. Dec.

Fig. 2. Thermal energy production at Riga CHP plants in 2014.

\section{B. Analysis of HOBs operation at Riga CHP plant No. 1}

The Fig. 3 provides the comparison of thermal energy production by HOBs in 2005, 2010 and 2014. The load increase of HOBs was during the heating period (October April), because it was not profitable to operate cogeneration units due to high natural gas price and low electricity price. For example, in 2014 HOBs have produced approximately 100 GWh during the winter, but thermal energy production has decreased to zero during the summer.

The Tab. 1 represents the HOBs No. 1, 2, 3 average thermal loads in 2014. From October to April all HOBs were in operation. Average thermal load of HOBs was $45-60 \mathrm{MW}$ during the coldest months and 33-45 MW during the months with higher ambient temperature, for example, in April, October, November and February. In summer the HOBs were not in operation. During the other months - May, August, and September - two HOBs were in operation. For instance, in May the HOBs No. 1 \& 2 were in operation, in August HOBs No. $2 \& 3$ and in September HOBs No. 1 \& No. 3. In August and September the HOBs load was low approximately 20 MW, but two HOBs were operated, because of security of supply.

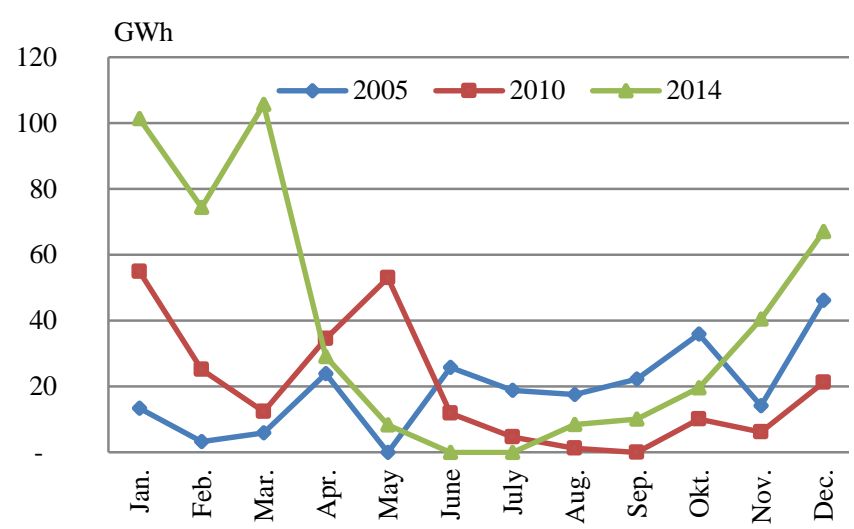

Fig. 3. Thermal energy production by HOBs at Riga CHP plant No. 1.

TABLE 1

Average LoAD of HOBs At Riga CHP Plant No. 1

\begin{tabular}{|l|l|l|l|}
\hline Average load, MW & HOB No. 1 & HOB No. 2 & HOB No. 3 \\
\hline January & 49.02 & 48.05 & 44.19 \\
\hline February & 45.63 & 39.85 & 44.19 \\
\hline March & 55.64 & 54.99 & 53.71 \\
\hline Aril & 35.87 & 30.64 & 40.98 \\
\hline May & 31.18 & 44.97 & - \\
\hline June & - & - & - \\
\hline July & - & - & - \\
\hline Augusts & - & 18.41 & 15.04 \\
\hline September & 18.53 & & 20.30 \\
\hline October & 42.64 & 35.46 & 43.43 \\
\hline November & 33.45 & 43.89 & 40.90 \\
\hline December & 47.72 & 58.69 & 53.80 \\
\hline
\end{tabular}

\section{Analysis of HOBs operation at Riga CHP plant No. 2}

The similar situation can be observed at Riga CHP plant No. 2. The HOBs have produced $170 \mathrm{GWh}$ in winter in 2014. But in summer thermal energy production decreased to zero (Fig. 4).

Table 2 presents the average load of HOBs in 2014. From January to March the data were not available, that is why it is very difficult to judge about HOBs operation during these months. From October to December five $\mathrm{HOBs}$ were in operation. The HOBs load was about $75 \mathrm{MW}$. From April to July two HOBs were in operation: HOBs No. $2 \&$ No. 3 or HOBs No. 4 \& No. 5. In August, thermal energy demand was 
very low, that is why it was difficult to operate two HOBs, as it is correct from security of supply point of view. So HOB No. 5 was in operation. Its average load was $30 \mathrm{MW}$. HOBs were not operated in September (Table 2).

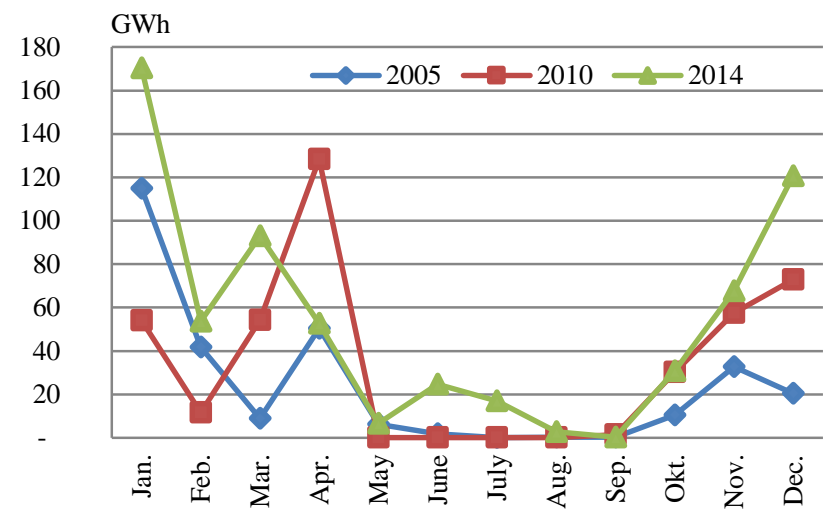

Fig. 4. Thermal energy production of HOBs at Riga CHP plant No. 2.

TABLE 2

AvERAGE LOAD OF HOBS AT Riga CHP-2

\begin{tabular}{|l|l|l|l|l|l|}
\hline $\begin{array}{l}\text { Average load, } \\
\text { MW }\end{array}$ & $\begin{array}{l}\text { HOB } \\
\text { No. 1 }\end{array}$ & $\begin{array}{l}\text { HOB } \\
\text { No. 2 }\end{array}$ & $\begin{array}{l}\text { HOB } \\
\text { No. 3 }\end{array}$ & $\begin{array}{l}\text { HOB } \\
\text { No. 4 }\end{array}$ & $\begin{array}{l}\text { HOB } \\
\text { No. 5 }\end{array}$ \\
\hline January & No data & No data & No data & No data & No data \\
\hline February & No data & No data & No data & No data & No data \\
\hline March & No data & No data & No data & No data & No data \\
\hline April & 5.95 & 66.97 & 56.42 & - & 19.66 \\
\hline May & - & 1.25 & 1.11 & 31.00 & 10.75 \\
\hline June & - & - & - & 49.78 & 19.11 \\
\hline July & - & - & - & 37.80 & 27.25 \\
\hline August & - & - & - & - & 29.49 \\
\hline September & - & - & - & - & - \\
\hline October & 48.37 & 52.17 & 39.75 & 41.82 & 50.64 \\
\hline November & 55.70 & 59.98 & 58.00 & 66.46 & 62.35 \\
\hline December & 71.70 & 74.64 & 60.71 & 68.78 & 55.83 \\
\hline
\end{tabular}

D. Arguments in favor of passive condensing economizer installation at Riga CHP plants

Riga CHP plants have modern equipment and best available technologies. But it was found that it is not enough in line with modern development tendencies:

1) Changeable situation in the markets: fluctuation of electricity and natural gas prices;

2) Competition increase between energy production companies;

3) Strict legislation requirements;

4) other.

According to the results of analysis of Riga CHP plants operational data, the forecasted operation conditions of Riga CHP plants in the future can be the following: HOBs will be used more than cogeneration units. Moreover, they will be operated in base load instead of peak mode. In this way, the efficiency of heat only boilers can be improved through installation of passive condensing economizer.
As it was mentioned, passive condensing economizer has some limitations of use at cogeneration power plants. But selection of appropriate connection scheme of economizer could solve this problem. This scheme supposes connection of the cold water pipe's (which is circulating through flue gas condensing economizer and condensing exhaust gas) input /output to return water pipes of district heating system. In this way, it is possible to increase the efficiency of condensing economizer.

\section{PASSIVE EXHAUST GAS CONDENSING ECONOMIZER INSTALLATION AT RIGA CHP PLANTS}

To evaluate the capacity of exhaust gas condensing economizer, the relationship between the outdoor temperature and condensing economizer capacity was derived (Fig. 5).

This relation $Q_{\text {condenser }}=f(T)$ can be described with such equation

$$
Q_{\text {condenser }}=0.2 \times T+7.7
$$

where

$Q_{\text {condenser }}$ - Condensing economizer capacity, [MW];

$T$ - Outdoor temperature, $\left[{ }^{\circ} \mathrm{C}\right]$.

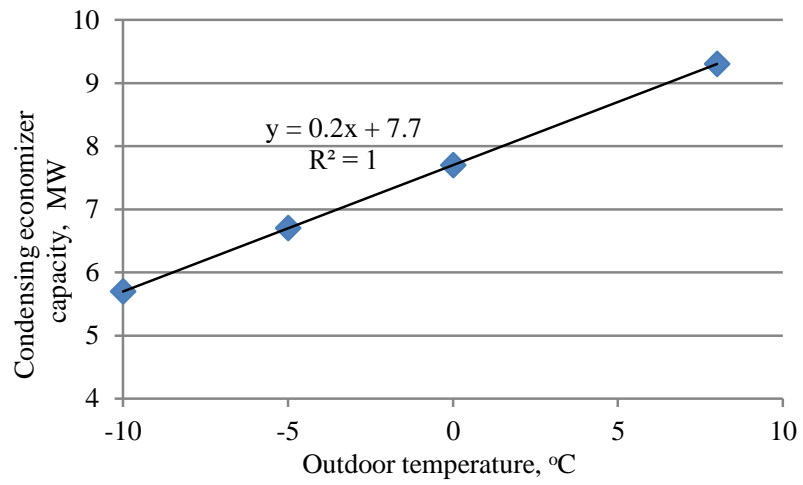

Fig. 5. Exhaust gas condensing economizer capacity as function from the outdoor temperature.

To get equation (1), the data of similar project was used and analyzed. At the central heating station Imanta water heating boiler KVGM - 100 was equipped with $10 \mathrm{MW}$ condensing economizer. The investments costs of this project were 879,067 EUR (without VAT), which were used as an example to estimate the investments costs of exhaust gas condensing economizer installation at Riga CHP plants No. 1 and No. 2

\section{A. Considered options of exhaust gas condensing economizer} installation at Riga CHP plant No. 1 and No. 2

It is recommended to study two options of exhaust gas condensing economizer installation at Riga CHP plant No. 1 and three options - at Riga CHP plant No. 2. The considered options are presented in Table 3.

Options No. $2 \& 5$ suppose installation of one condensing economizer for two HOBs. The other options (No. 1, No. 3, No. 4) suppose installation of one condensing economizer for one HOB. 
TABLE 3

CONSIDERED OPTIONS

\begin{tabular}{|c|c|c|c|}
\hline Options & CHP plant & $\begin{array}{l}\text { Economizer connected to } \\
\text { boilers No. }\end{array}$ & $\begin{array}{l}\text { Investment } \\
\text { volumes, thous. } \\
€ \text { (without VAT) }\end{array}$ \\
\hline 1 & \multirow{2}{*}{$\begin{array}{l}\text { Riga } \\
\text { CHP-1 }\end{array}$} & HOB No. 3 & 966.1 \\
\hline 2 & & HOB No. $1 \&$ No. 2 & $1,549.8$ \\
\hline 3 & \multirow{3}{*}{$\begin{array}{l}\text { Riga } \\
\text { CHP-2 }\end{array}$} & HOB No. 5 & 957.9 \\
\hline 4 & & HOB No. 4 & $1,188.5$ \\
\hline 5 & & HOB No. 4 \& No. 5 & $1,763.3$ \\
\hline
\end{tabular}

\section{B. Aspects of option evaluation and best option choice}

In line with operational data analysis, the production programmes of five options were developed. Then the economic evaluation of options was performed: the payback time, net present value (NPV) and internal rate of return (IRR) were calculated. The best option of installation of condensing economizer for CHP plant No. 1 and CHP plant No. 2 was chosen as the result of this evaluation. Next, the sensitivity analysis of the best options was done under five conditions:

1) Thermal load loss during the summer. So natural gas HOBs are not in operation. The thermal load is provided by biomass HOB in summer;

2) Natural gas price reduction by $15 \%$;

3) Thermal load reduction by $50 \%$;

4) Thermal load reduction by $50 \%$ and natural gas price reduction by $15 \%$;

5) Operation only in winter months.

\section{Justification of condensing economizer installation at Riga CHP plant No. 1}

According to ambient conditions in 2014 and equation (1), it was calculated that the necessary capacity of exhaust gas condensing economizer for HOB No. 3 is $2-4 \mathrm{MW}$ (Option No. 1) and for HOBs No. 1 \& No. 2 is 5-8 MW (Option No. 2).

In line with production programmes of Option No. $1 \& 2$ it was calculated that Option No. 1 ensures approximately two times more natural gas saving and $\mathrm{CO}_{2}$ emissions reduction (Fig. 6).

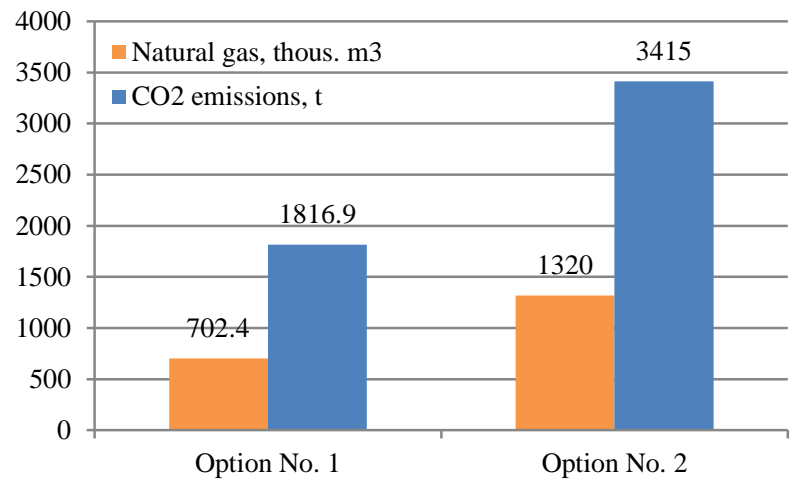

Fig. 6. Evaluation of Options No. $1 \& 2$ benefits.

The results of the economic analysis of Options No. $1 \& 2$ are presented in Table 4. So Option No. 2 provides the best results: payback time is 2.3 years shorter and IRR is $14.5 \%$ higher, than for Option No. 1.
TABLE 4

RESUlTS OF OPTIONS ECONOMIC EVALUATION AT RIGA CHP-1

\begin{tabular}{|l|l|l|l|l|}
\hline $\begin{array}{l}\text { Option } \\
\text { No. }\end{array}$ & HOB & $\begin{array}{l}\text { Payback } \\
\text { time, years }\end{array}$ & $\begin{array}{l}\text { NPV for the } 10^{\text {th }} \\
\text { year, thous. EUR }\end{array}$ & $\begin{array}{l}\text { IRR for the } \\
10^{\text {th }} \text { year, } \%\end{array}$ \\
\hline 1 & No.3 & 5.75 & 521.5 & 16.9 \\
\hline 2 & $\begin{array}{l}\text { No. } 1 \& \text { No. } \\
2\end{array}$ & 3.42 & $2,195.5$ & 31.4 \\
\hline
\end{tabular}

The results of Option No. 2 sensitivity analysis are provided in Table 5.

TABLE 5

RESUlTS OF OPTION NO. 2 SENSITIVITY ANALYSIS

\begin{tabular}{|c|l|l|l|l|}
\hline No. & $\begin{array}{l}\text { Conditions of } \\
\text { sensitivity analysis }\end{array}$ & $\begin{array}{l}\text { Payback } \\
\text { time, } \\
\text { years }\end{array}$ & $\begin{array}{l}\text { NPV for the } \\
10^{\text {th }} \text { year, } \\
\text { thous. EUR }\end{array}$ & $\begin{array}{l}\text { IRR for } \\
\text { the } 10^{\text {th }} \\
\text { year, } \%\end{array}$ \\
\hline 1. & $\begin{array}{l}\text { Thermal load loss } \\
\text { during the summer }\end{array}$ & 3.45 & $2,163.9$ & 31.1 \\
\hline 2. & $\begin{array}{l}\text { Natural gas price } \\
\text { reduction by } 15 \%\end{array}$ & 4.03 & $1,679.1$ & 26.1 \\
\hline 3. & $\begin{array}{l}\text { Thermal load } \\
\text { reduction by } 50 \%\end{array}$ & 7.45 & 385.7 & 11.5 \\
\hline 4. & $\begin{array}{l}\text { Thermal load } \\
\text { reduction by } 50 \% \text { and } \\
\text { natural gas price } \\
\text { reduction by } 15 \% .\end{array}$ & 8.96 & 130.5 & 8.3 \\
\hline 5. & $\begin{array}{l}\text { Operation only in } \\
\text { winter months }\end{array}$ & 10.38 & -45.3 & 5.9 \\
\hline
\end{tabular}

Such conditions as thermal load loss during the summer and natural gas price reduction have less influence on Option No. 2 profitability. The payback time increase is approximately 1 year and IRR decrease is 5\%. Thermal load reduction by $50 \%$ impairs profitableness of Option No. 2 approximately twice. Option No. 2 becomes disadvantageous under two conditions: HOBs is operated only in winter and thermal load reduction by $50 \%$ and natural gas price reduction by $15 \%$ happen at the same time.

There are some complications with condensing economizer connection to HOBs No. 1 \& 2 flue gas pipes. The space between the HOBs house and smoke stack is fully-equipped with communication such as flue pipes, smoke exhausters, service areas, etc. (Fig. 7).

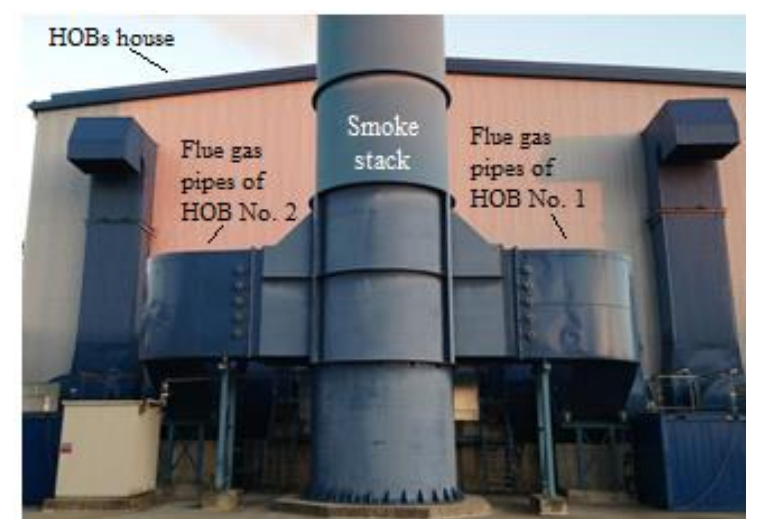

Fig. 7. Connection of HOBs No. 1 \& 2 flue pipes to the smoke stack at CHP-1. 
That is why it is offered to locate the condensing economizer further from the HOBs No. 1 \& 2 smoke stack. So longer connection flue gas pipes will be necessary. It was observed evaluating the investment costs of Option No 2.

\section{Justification of condensing economizer installation at Riga CHP plant No. 2}

According to ambient conditions in 2014 and equation (1), it was calculated that the necessary capacity of exhaust gas condensing economizer for Option No. 3 \& 4 is $2-5 \mathrm{MW}$ (HOB No. 5 and HOB No. 4) and for Option No. 5 is 4-9 MW (HOB No. 5 \& 4).

In line with production programmes of Option No. 2, 3, 4, natural gas saving and $\mathrm{CO}_{2}$ emissions reduction were estimated. One condenser economizer installation to two HOBs No. 4 \& 5 provides approximately two time more natural gas saving and $\mathrm{CO}_{2}$ emissions reduction than in case of CHP-1 (Fig. 8).

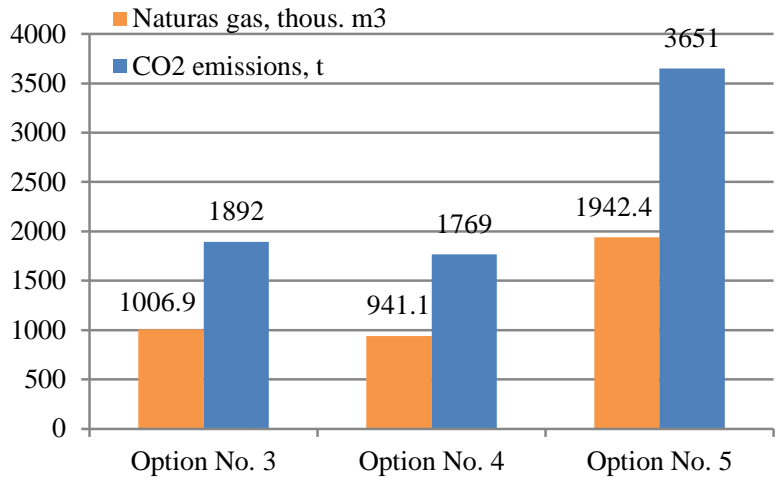

Fig. 8. Evaluation of Options No. 3, 4, 5 benefits.

The results of economic analysis of Options No. 3, 4, 5 are presented in Table 6. Option No. 5 provides the best results. So in both cases (CHP-1 and CHP-2) it is more profitable to install one condenser economizer to two HOBs.

TABLE 6

RESUlts OF OPTIONS ECONOMIC EVALUATION AT RigA CHP-2

\begin{tabular}{|l|l|l|l|l|}
\hline $\begin{array}{l}\text { Option } \\
\text { No. }\end{array}$ & HOB & $\begin{array}{l}\text { Payback time, } \\
\text { years }\end{array}$ & $\begin{array}{l}\text { NPV for the } 10^{\text {th }} \\
\text { year, thous. EUR }\end{array}$ & $\begin{array}{l}\text { IRR for the } \\
10^{\text {th }} \text { year, \% }\end{array}$ \\
\hline 3 & No. 5 & 3.84 & $1,128.3$ & 27.7 \\
\hline 4 & No. 4 & 5.23 & 792.9 & 19.2 \\
\hline 5 & No. $4 \& 5$ & 3.65 & $2,252.2$ & 29.2 \\
\hline
\end{tabular}

Results of Option No. 5 sensitivity analysis are provided in Table 7. The results of sensitivity analysis are the same as in case of CHP-1.

TABLE 7

RESULTS OF OPTION NO. 5 SENSITIVITY ANALYSIS

\begin{tabular}{|l|l|l|l|l|}
\hline No. & $\begin{array}{l}\text { Conditions of sensitivity } \\
\text { analysis }\end{array}$ & $\begin{array}{l}\text { Payback } \\
\text { time, years }\end{array}$ & $\begin{array}{l}\text { NPV for the } \\
10^{\text {th }} \text { year, } \\
\text { thous. EUR }\end{array}$ & $\begin{array}{l}\text { IRR for } \\
\text { the } 10^{\text {th }} \\
\text { year, \% }\end{array}$ \\
\hline 1. & $\begin{array}{l}\text { Thermal load loss during } \\
\text { the summer }\end{array}$ & 4.37 & $1,665.9$ & 23.9 \\
\hline 2. & $\begin{array}{l}\text { Natural gas price } \\
\text { reduction by 15\% }\end{array}$ & 4.32 & $1,700.2$ & 24.2 \\
\hline
\end{tabular}

\begin{tabular}{|l|l|l|l|l|}
\hline 3. & $\begin{array}{l}\text { Thermal load reduction } \\
\text { by } 50 \%\end{array}$ & 8.00 & 319.5 & 10.2 \\
\hline 4. & $\begin{array}{l}\text { Thermal load reduction } \\
\text { by } 50 \% \text { and natural gas } \\
\text { price reduction by } 15 \% .\end{array}$ & 10.20 & -25.4 & 6.2 \\
\hline 5. & $\begin{array}{l}\text { Operation only in winter } \\
\text { months }\end{array}$ & 12.21 & -256.1 & 3.3 \\
\hline
\end{tabular}

There are no complications with condensing economizer connection at Riga CHP-2, because there is free space between HOBs house and HOBs smoke stack (Fig. 9). That is why two connection schemes are offered.

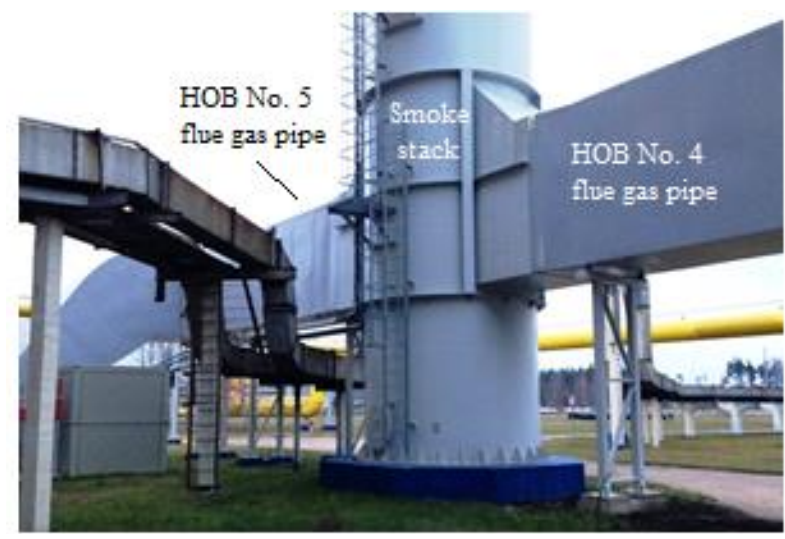

Fig. 9. Connection of HOBs No. $4 \& 5$ flue pipes to the smoke stack at CHP-2.

Both connection schemes provide that condensing economizer flue gas pipes (input/output) are connected to the HOBs flue gas pipes. The schemes differ in condensing economizer water pipes (input/output) connection.

In case of connection scheme No. 1, the water pipes (input / output) are connected to the main district heating system return water pipes (Fig. 10).

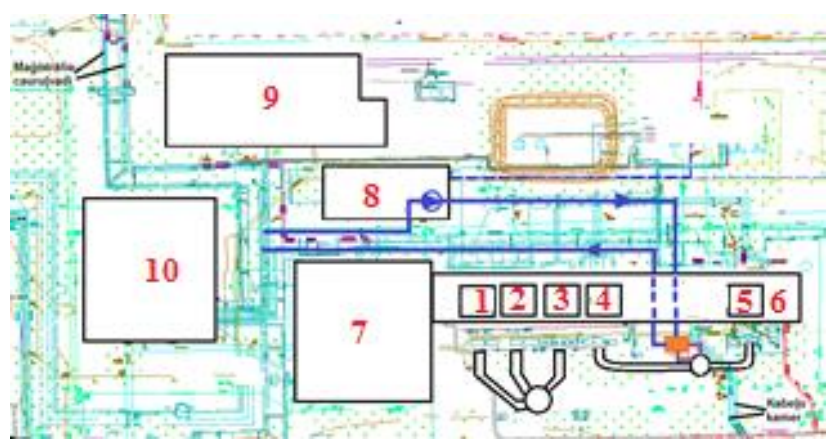

Fig. 10. Connection scheme No. 1.

(1. HOB No. $1 ; 2$. HOB No. $2 ; 3$. HOB No. $3 ; 4$. HOB No. $4 ; 5$. HOB No. 5 ; 6. HOBs house; 7. Pumping station of the heating system; 8. Distribution of the main heating system; 9 . Storehouse of chemical reagents; 10 . Storehouse of inflammable materials)

Connection scheme No. 2 ensures condensing economizer water pipes (input / output) connection to the piping of the first grade pumps (DN 800) (Fig. 11).

After evaluating both connection schemes, it is considered that connection scheme No. 2 is better than connection scheme No. 1. It is not advisable to connect additional pipes to the main return water pipes (DN 1000 and $\mathrm{DN}$ 1200) as 
connection scheme No. 1 provides, because it will be more expensive and can reduce security of supply.

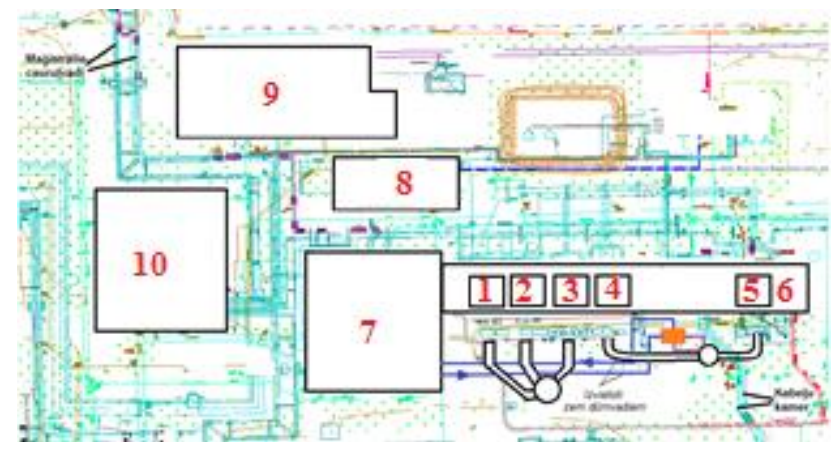

Fig. 11. Connection scheme No. 2.

(1. HOB No. 1 ; 2. HOB No. 2; 3 . HOB No. 3 ; 4. HOB No. 4 ; 5 . HOB No. 5 ; 6. HOBs house; 7. Pumping station of the heating system; 8. Distribution of the main heating system; 9. Storehouse of chemical reagents; 10. Storehouse of inflammable materials)

\section{CONCLUSIONS}

This study attests that it is profitable to install passive condensing economize at Riga CHP-1 and Riga CHP-2. In case of Riga CHP-1 it is Option No. 2 and in case of Riga CHP-2 it is Option No. 5. Both options provide one condensing economizer installation for two water heating boilers. The nominal capacity of condensing economizer is about $10 \mathrm{MW}$.

At first it is recommended to install condensing economizer at Riga CHP plant No. 2, because there HOBs are more in operation. Also there are no complications with connection of the passive condensing economizer: two possible connection schemes of condensing economizer are available for Riga CHP plant No. 2.

\section{REFERENCES}

[1] Q. Chen, K. Finney, H. Li, X. Zhang, J. Zhou, V. Sharifi, J. Swithenbank, "Condensing boiler applications in the process industry," Applied Energy, vol. 89, pp. 30-36, Jan. 2012. http://dx.doi.org/10.1016/j.apenergy.2010.11.020

[2] A. Kudrikov, "Energy saving in energy generation equipment," Uljanovsk: Uljanocskij Technical university, 2000, pp. 139. [Online]. Available: http://venec.ulstu.ru/lib/2002/1/Kudinov_2.pdf [Accessed: March 2, 2015].

А. Кудинов, ,ЭЭергосбережение в теплогенерирующих установках, , Ульяновск: УлГТУ, 2000, 139 с.

[3] Method of deep flue gas heat utilization (Метод глубокой утилизации тепла дыммовых газов)

Available: http://www.energosovet.ru/entech.php?idd=3 [Accessed: March 2, 2015]

[4] A. Zigurs, A. Cers, J. Golunovs, D. Turlajs, S. Pliskachev, „Flue gas utilization at Riga thermal energy source" May 2010. [Online]. Available: http://www.rosteplo.ru/Tech_stat/en_2765.pdf [Accessed: March 2, 2015].

А. Жигурс, А. Церс, Ю. Голуновс, Д. Турлайс, С. Плискачев, „Утилизация тепла дылмовых газов на теплоисточниках г. Риги," Май 2010.

[5] JSC Latvenergo, "JSC Latvenergo power plant aggregates" 2013 